\title{
Prediction Of Ultimate Load Capacity Of High-Strength Reinforced Concrete Corbels Ali Ramadhan Yousif
}

Assist. Professor

Civil Engineering Department/College of Engineering/university of Salahaddin-Erbil/Iraq

\begin{abstract}
A study on the behavior of reinforced high-strength concrete corbels is carried out using nonlinear finite element analysis and a simplified softened strut-and-tie model. In the numerical analysis, eight-node isoparametric plane stress elements are employed to model the concrete material. An elastic-strain hardening plasticity approach combined with cracking damage is used in modeling the concrete behavior. The reinforcing bars are treated as embedded elements and are considered as elastic-perfectly plastic material. In the analytical method, the analysis is based on truss analogy following the provisions of Appendix A of the ACI 318-05 Code. Strength predictions of both methods correlate well with the 34 test results of corbels available from the literature. It was concluded that the adopted finite element model is a powerful tool for the analysis of such disturbed region. Also the simple truss model used proved to be a suitable design tool for these members. The finite element method can be used in conjunction with the truss analogy for optimum design.
\end{abstract}

Keywords: corbels; deep beams; finite element; non-flexural members; plasticity; shear strength; strut-and-tie models.

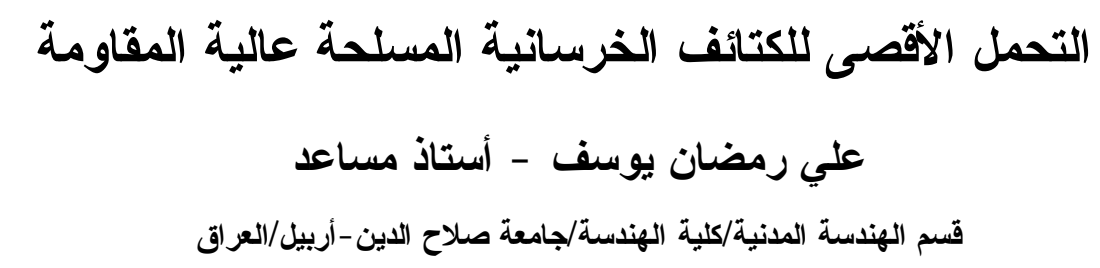

الخلاصة

تم في هذا البحث دراسة سلوك الكتائف الخرسانية المسلحة عالية المقاومة بالتحليل غير الخطي بأستخدام

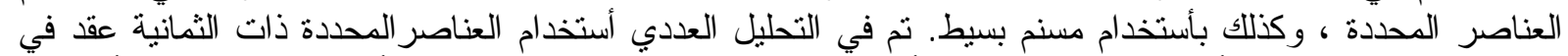

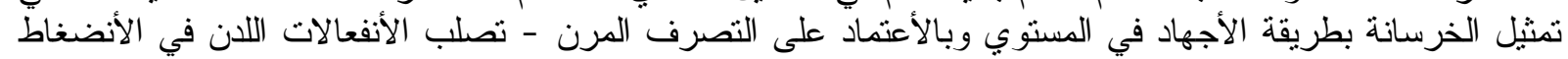

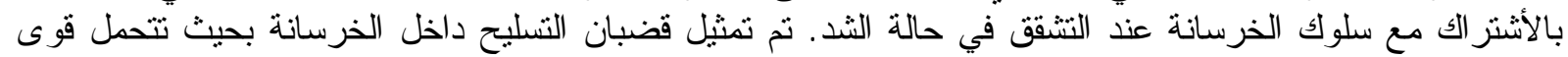

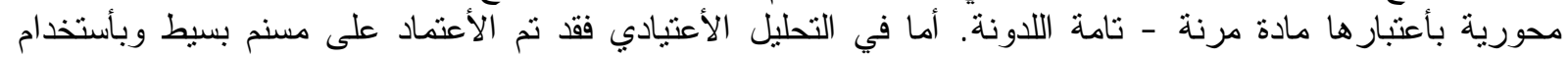

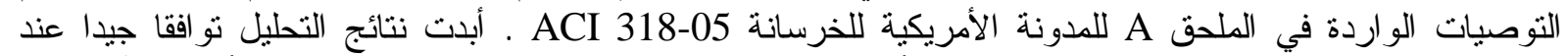

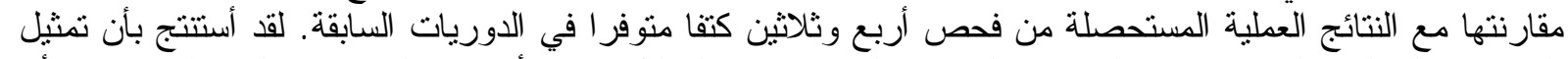

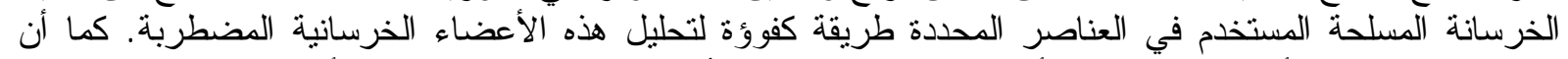

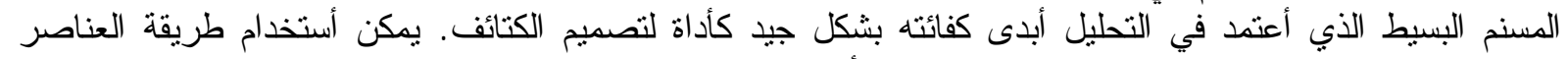
المحددة وبالتداخل مع طريقة المسنمات للحصول على أفضل لصنل تصميم. 


\section{$\begin{array}{llll}\text { Al-Rafidain Engineering } & \text { Vol.17 } & \text { No.4 } & \text { August } 2009\end{array}$}

\section{Introduction}

Corbels are brackets that project from the face of columns and are used extensively in precast concrete construction to support primary beams and girders. Because of the prevalence of precast concrete, the design of corbels has become increasingly important. The term "corbel" is generally restricted to cantilevers having shear span-depth ratio less than unity. Such a small ratio causes the strength of corbels to often be controlled by shear, which is similar to deep beams.

Corbels are designed mainly to provide the vertical reaction $\mathrm{V}_{\mathrm{u}}$ at the end of a supported beam, but unless special precautions are taken to avoid horizontal forces caused by restrained shrinkage, creep (in the case of prestressed beams), or temperature change, they must also resist a horizontal force $\mathrm{H}_{\mathrm{u}}$. Steel bearing plates or angles are generally used on the top surface of the corbels to provide a uniform contact surface and to distribute the reaction. A corresponding steel bearing plate or angle is usually provided at the lower corner of the supported member. Even with Teflon or elastomeric bearing pads, frictional forces will develop due to volumetric change.

In tests, corbels display several modes of failure, the most common of which are yielding of the tension reinforcement, crushing or splitting of the compression strut that develops between the loading plate and the junction of the column and the sloping face of the corbel, and localized bearing or shearing failure under the loading plate. Typically, reinforcement for the corbel has consisted of primary tension steel, horizontal hoops, and framing bars.

The researchers who conducted experimental studies using normal-strength concrete [1-6] concluded that the shear strength is a function of: (1) Shear-span-to-depth ratio; (2) reinforcement ratio; (3) concrete strength; and (4) the ratio of the horizontal to vertical components of the applied loads. A minimum amount of horizontal stirrup reinforcement must be provided to avoid diagonal tension failure. It was also reported that in most cases the primary reinforcement steel yielded before failure. Based on these results, shear-span-to-depth (a/d) and reinforcement ratios were chosen as the primary variables.

Increase in concrete strength can be expected to increase the shear strength of the corbel. However, since high-strength concrete is typically more brittle than normal-strength concrete, it should be ascertained that higher strength can be used without leading to catastrophic brittle failure. Yielding of steel reinforcement prior to failure and extensive cracking typically lead to ductile failure.

The researchers who conducted experimental studies using high-strength concrete [710] concluded that the behavior of high-strength concrete corbels is similar to that of normalstrength concrete corbels, and that the increase in concrete strength does not adversely affect the ductility of the corbel provided that a nominal amount of stirrup reinforcement is used.

\section{Research Significance}

While a considerable amount of research has been performed on corbels in general, little exists in conjunction with high-strength concrete. This paper presents numerical and analytical investigations of the ultimate load capacity of corbels made of high-strength concrete. Different parameters such as shear-span-to-depth ratio, primary reinforcement ratio, secondary reinforcement ratio, and concrete compressive strength have been studied. The study shows that the finite element method is a suitable tool for the analysis of high-strength concrete corbels, and that the strut-and-tie model is a simple and effective design tool for such disturbed member. 


\section{Analysis Methods}

\section{1-Numerical Analysis}

Nonlinear analysis is a very powerful tool that satisfies, at every load stage, displacement compatibility and equilibrium. From the constitutive laws for concrete and steel, the complete behavior of a structure can be predicted until collapse. However, such analysis will generally require extensive use of computer procedures and enormous amount of data, which in general, is not compatible with practicability and time demands. Nonlinear analysis requires also the initial definition of geometry and reinforcement. Therefore it should be regarded as an almost accurate tool to verify the safety of a structure for both service and ultimate loads. A brief description of the nonlinear finite element model used in this study for the analysis of corbels (disturbed region) made of high-strength concrete is presented here.

\section{Model Description}

Description of the highly complex behavior of concrete is a difficult task and to date generally accepted constitutive equations do not exist. A variety of models have been proposed to characterize the stress-strain relations and failure behavior of concrete material under multi-axial stress states [11]. All these models have certain inherent advantages or disadvantages, which depend to a large degree, on the particular application considered [12]. Details of the approach adopted here are given in Ref. [12] and only a brief summary is provided here.

Experimental evidence indicates that the stress-strain relationship for concrete is nonlinear even for low stress levels. The inelastic deformation may be separated into recoverable and irrecoverable components. In the present model, elasticity theory is used for the recoverable strain components and a strain-hardening plasticity approach is employed to model the irrecoverable parts of the deformation.

\section{Compressive Behavior of Concrete}

Four conditions have to be established to be able to evaluate the nonlinear compressive behavior of concrete, these are: the yield condition, the flow rule, the hardening rule, and the crushing condition.

\section{(a) The yield condition:}

Under a triaxial stress state the yield criterion for concrete is generally assumed to be dependent on the three stress invariants $\left(\mathrm{I}_{1}, \mathrm{~J}_{2}, \mathrm{~J}_{3}\right)$. A dependence of the yield function on the mean normal stress invariant $I_{1}$ and the shear stress invariant $J_{2}$, has proved to be adequate for most practical applications [12]. The yield criterion adopted here is of such type [12], and can be written as:

$$
\mathrm{f}\left(\mathrm{I}_{1}, \mathrm{~J}_{2}\right)=\left\{\beta\left(3 \mathrm{~J}_{2}\right)+\alpha \mathrm{I}_{1}\right\}^{1 / 2}=\sigma_{0}
$$

where $\alpha$ and $\beta$ are two material parameters and $\sigma_{0}$ is the equivalent effective stress. For plane stress problems, $\mathrm{I}_{1}$ and $\mathrm{J}_{2}$ are given by [11]:

$I_{1}=\sigma_{x}+\sigma_{y} ; J_{2}=1 / 3\left\{\sigma_{x}^{2}+\sigma_{y}^{2}-\sigma_{x} \sigma_{y}\right\}+\tau^{2}{ }_{x y}$

If Kupfer's [13] results are employed $\left(\mathrm{f}_{\mathrm{bc}}=1.16 \mathrm{f}^{\prime} \mathrm{c}\right)$, the material constants for plain concrete are: $\quad \alpha=0.355 \sigma_{0} ; \quad \beta=1.355$

This resulting yield criterion compared well with the experimental results of Kupfer et al. [13] in biaxial stress space [12,14]. 


\section{$\begin{array}{llll}\text { Al-Rafidain Engineering } & \text { Vol.17 } & \text { No.4 } & \text { August } 2009\end{array}$}

This yield criterion can be used as the basis for an elastic-perfectly plastic model if $\sigma_{0}$ is taken to be equal to the compressive strength, $\mathrm{f}{ }^{\prime}$, obtained from uniaxial test. It is more realistic to use a work-hardening model in which $\sigma_{0}$ is a function of a hardening parameter. A value of $\mathrm{c} \mathrm{f}^{\prime}{ }_{\mathrm{c}}$ defines a surface limiting the elastic behavior. A typical value of $\mathrm{c}$ is 0.30 [14]. When this surface is reached inelastic deformation begins and a hardening rule monitors the expansion of the yield surface under further loading.

In the elastic range, the incremental stress-strain relationship of the material is given by:

$$
\mathrm{d}\{\sigma\}=\left[\mathrm{D}^{\mathrm{e}}\right] \mathrm{d}\{\varepsilon\}
$$

where $d\{\sigma\}$ and $d\{\varepsilon\}=$ stress and strain increment vectors, respectively; and $\left[D^{\mathrm{e}}\right]=$ elastic matrix of material constants. In the plastic range, the elastic component $\left[\mathrm{D}^{\mathrm{e}}\right]$ degrades with increasing damage. During the occurrence of plastic flow, the total strain increments in the material may be decomposed into elastic and plastic components, i.e.

$$
\mathrm{d}\{\varepsilon\}=\mathrm{d}\left\{\varepsilon^{\mathrm{e}}\right\}+\mathrm{d}\left\{\varepsilon^{\mathrm{p}}\right\}
$$

where $\mathrm{d}\left\{\varepsilon^{\mathrm{e}}\right\}$ and $\mathrm{d}\left\{\varepsilon^{\mathrm{p}}\right\}=$ vectors of the elastic- and plastic-strain increments, respectively. The elastic component of the strain increment vector may be related to the total stress increment using Eqn. (2), whereas the plastic-strain increment vector is evaluated from the stress increment through the use of a flow rule.

\section{(b) The flow and hardening rule:}

The yield function derivatives which define the flow vector $\{a\}$ for a plane stress problem can be evaluated as:

$$
\{\mathrm{a}\}^{\mathrm{T}}=\left\{\partial \mathrm{f} / \partial \sigma_{\mathrm{x}}, \partial \mathrm{f} / \partial \sigma_{\mathrm{y}}, \partial \mathrm{f} / \partial \tau_{\mathrm{xy}}\right\}
$$

The complete elasto-plastic incremental stress-strain relation is given by the expression:

with:

$$
\mathrm{d}\{\sigma\}=\left[\mathrm{D}^{\mathrm{ep}}\right] \mathrm{d}\{\varepsilon\}
$$

$$
\left[\mathrm{D}^{\mathrm{ep}}\right]=\left[\mathrm{D}^{\mathrm{e}}\right]-\frac{\left[\mathrm{D}^{\mathrm{e}}\right]\{\mathrm{a}\}\{\mathrm{a}\}^{\mathrm{T}}\left[\mathrm{D}^{\mathrm{e}}\right]}{\left(\mathrm{H}+\{\mathrm{a}\}^{\mathrm{T}}\left[\mathrm{D}^{\mathrm{e}}\right]\{\mathrm{a}\}\right)}
$$

where $\left[\mathrm{D}^{\mathrm{ep}}\right]$ is the elasto-plastic modulus matrix, $\mathrm{H}^{-}$is the hardening parameter, and $\left[\mathrm{D}^{\mathrm{e}}\right]$ is the elastic constitutive matrix which for plane stress problem can be written as [11]:

$$
\left[\mathrm{D}^{\mathrm{e}}\right]=\frac{\mathrm{E}}{(1+v)(1-v)}\left[\begin{array}{ccc}
(1) & v & 0 \\
v & 1 & 0 \\
0 & 0 & \frac{(1-v)}{2}
\end{array}\right]
$$

In the present work the relation between effective stress and effective plastic strain is extrapolated from the uniaxial stress-strain relationship given by:

$$
\sigma_{0}=\mathrm{E}_{0} \varepsilon-\mathrm{E}_{0} \varepsilon^{2} /\left(2 \varepsilon_{0}\right)
$$

where $\sigma_{0}$ is the effective stress, $\mathrm{E}_{0}$ is the initial Young's modulus, $\varepsilon$ is the current total strain, and $\varepsilon_{0}$ is the total strain at peak stress, $\mathrm{f}{ }^{\prime}$. A complete presentation of the flow vector parameters, hardening rule parameters, and the uniaxial stress-strain parameters can be found in reference [12].

\section{(c) The crushing condition:}

The crushing type of failure is a strain-controlled phenomenon. Limiting strain criterion being developed by simply converting the yield criterion described in terms of stresses directly into strains. Thus: 


$$
\beta\left(3 \mathrm{~J}_{2}\right)+\alpha \mathrm{I}_{1}=\varepsilon_{\mathrm{cu}}^{2}
$$

where $I_{1}$ and $J_{2}$ are strain invariants [11], and $\varepsilon_{\mathrm{cu}}$ is an ultimate total strain extrapolated from uniaxial test results, taken in practical examples in the range of $0.003-0.0035$ (taken as 0.003 in this study), the previous values of material parameters $\alpha$ and $\beta$ obtained from Kupfer's results can be adopted.

\section{Cracked Concrete Behavior in Compression}

Many experimental studies [15-17] provide strong evidence that the ability of diagonally cracked concrete to resist compression decreases as the amount of tensile straining increases. Various relationships for the compressive strength of diagonally cracked concrete are suggested, but only three of these relationships which are suitable for numerical analysis are presented here:

i- Vecchio and Collins [15] suggested: $\left(f_{c}\right)_{\max }=\frac{f^{\prime}{ }_{c}}{\left(0.8+34 \varepsilon_{1} / \varepsilon_{0}\right)} \leq f^{\prime}{ }_{c}$

$$
\text { ii- Belarbi and Hsu [16] suggested: } \quad\left(f_{c}\right)_{\max }=\frac{0.9 f^{\prime}{ }_{c}}{\sqrt{\left.1+400 \varepsilon_{1}\right)}}
$$

iii- Kaufmann and Marti [17] suggested: $\left(f_{c}\right)_{\max }=\frac{\left(f^{\prime}{ }_{c}\right)^{2 / 3}}{\left(0.4+30 \varepsilon_{1}\right)} \leq f^{\prime}{ }_{c}$

In the present study the above three relationships were tried and it was found that the suggestion of Vecchio and Collins [15] (Eqn. 10) which was based on the compression field theory is the most reliable for the simulation of the true behavior of the structure.

\section{Tensile Behavior of Concrete}

A crack is assumed to form in a plane perpendicular to the direction of maximum principal tensile stress, when the maximum principal tensile stress exceeds the tensile strength of the concrete at any Gauss point. A maximum of two sets of fixed orthogonal cracks (fixed crack model) are allowed to form at each sampling point. The smeared crack approach was adopted for crack modeling.

When cracking occurs, the material is assumed to be in a state of uniaxial compression parallel to the cracks. After cracking, a tension stiffening model [18] (Eqn.14) was applied in the direction perpendicular to the crack and a reduced shear modulus is employed to simulate the aggregate interlock. In this work an approach proposed initially by Al-Mahaidi [19] was used for evaluating the cracked shear modulus of concrete. According to this approach the shear modulus of cracked concrete $G^{`}$ can be calculated as follows:

For concrete cracked in direction 1:

$$
G^{`}=\frac{0.4 G}{\left(\varepsilon_{1} / \varepsilon\right)}
$$

For concrete cracked in direction 2:

$$
G^{`}=\frac{0.4 G}{\left(\varepsilon_{2} / \varepsilon\right)}
$$

where:

$\mathrm{G}=$ uncracked shear modulus,

$\mathrm{G}^{\prime}=$ cracked shear modulus,

$\varepsilon_{1}=$ tensile strain in direction 1 ,

$\varepsilon_{2}=$ tensile strain in direction 2 , and 


\section{$\begin{array}{llll}\text { Al-Rafidain Engineering } & \text { Vol.17 } & \text { No.4 } & \text { August } 2009\end{array}$}

$\varepsilon=$ cracking strain of plain concrete. If the strain normal to the crack drops to a negative value (compression case), i.e. the crack is closed, the uncracked shear modulus is again used in the corresponding direction. by [18]:

For plain concrete, the relationship between stress and strain after cracking was given

$\mathrm{f}^{{ }_{\mathrm{t}}}=$ the tensile strength of concrete, $\mathrm{MPa}$, and equal to $0.3\left(\mathrm{f}^{\prime}{ }_{\mathrm{c}}\right)^{2 / 3}[20]$ when the tensile strength of concrete is not specified,

$\varepsilon_{\mathrm{t}}=$ the tensile strain at maximum tensile stress, $\mathrm{mm} / \mathrm{mm}$,

$\varepsilon_{\mathrm{m}}=$ the maximum tensile strain, $\mathrm{mm} / \mathrm{mm}$,

$$
\varepsilon_{\mathrm{m}}=\left\{3 \mathrm{G}_{\mathrm{c}} /\left(\mathrm{hf}_{\mathrm{t}}\right)\right\}+\varepsilon_{\mathrm{t}}
$$

$\mathrm{G}_{\mathrm{c}}=$ the fracture energy of plain concrete, $\mathrm{N} / \mathrm{m}$, and equal to $\mathrm{a}_{\mathrm{d}} \mathrm{f}_{\mathrm{cu}}{ }^{0.7}[20]$,

$a_{d}=a$ factor reflecting the influence of maximum aggregate size, $d_{\max }$ :

$a_{d}=6$ for $d_{\max }=16 \mathrm{~mm}, 10$ for $d_{\max }=32 \mathrm{~mm},\left(a_{d}=6\right.$ in this study), and

$\mathrm{f}_{\mathrm{cu}}=$ concrete cube compressive strength, MPa.

\section{Finite Element Formulation}

Eight-node serendipity plane stress elements are used in this study. This isoparametric element has been proved to simulate the structural behavior successfully and gives reasonable results. Its formulation can be found elsewhere [21]. A $2 \times 2$ Gauss point integration rule (reduced rule) was found to give more accurate results than the full (3x3) integration rule for this type of structure. The smeared crack approach with two orthogonal cracks (fixed cracking model) was used for crack representation.

The reinforcing bars are represented as embedded bars anywhere within the concrete elements with elastic-perfectly plastic behavior. Perfect bond was assumed between the reinforcement and the surrounding concrete. This type of representation allows the reinforcement to be treated as an integral part of the basic element, and its stiffness contribution can be evaluated by the principles of superposition. The computer program used is that of reference [18] (where applied to fibrous concrete) with little modifications to account for non-fibrous high-strength concrete.

For the purposes of brevity, a typical finite element mesh, loading, and support conditions are shown for a half (due to symmetry) of corbel PF2 in Fig. 1. The modified Newton-Raphson method with incremental-iterative procedure was used in the numerical analysis. Table 1 and Fig. 2 give details of the test specimens.

Comparisons of the results (crack patterns, deflection, main steel strain, and ultimate loads) obtained from the numerical analysis with those obtained from experiments for a number of typical specimens are shown in Figs. (3-8). The figures show reasonable agreements.

During the tests of some corbels (corbels: E1, E2, and E3), relatively thin plates (6 mm thick) were used at the supports. The results of the numerical analysis showed that more reliable results can be obtained if the supports were simulated (the fact which was recognized by other researchers [18,22]) by applying a portion of the load (in this study 0.11 of the applied load) at the two corners of the bearing plates in the reverse direction. While the simulation at the loading point was as shown in Fig. 1. 


\section{Yousif : Prediction Of Ultimate Load Capacity Of High-Strength Reinforced Concrete}

The results of the analysis in terms of $\mathrm{V}_{\text {test }} / \mathrm{V}_{\text {calculated }}$ are shown in Table 2. It can be seen that the adopted finite element model predicts the load capacity of the corbels very well, and that this is a powerful technique for investigating such disturbed regions.

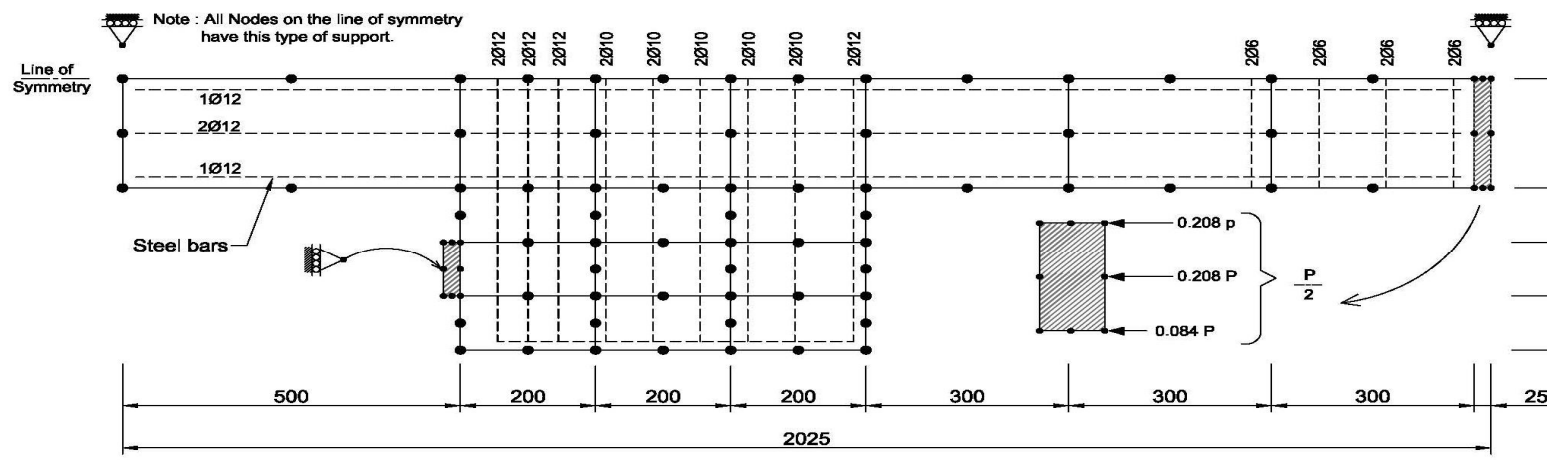

Fig.(1) - Finite Element Mesh and layout of steel bars for corbels: PF2

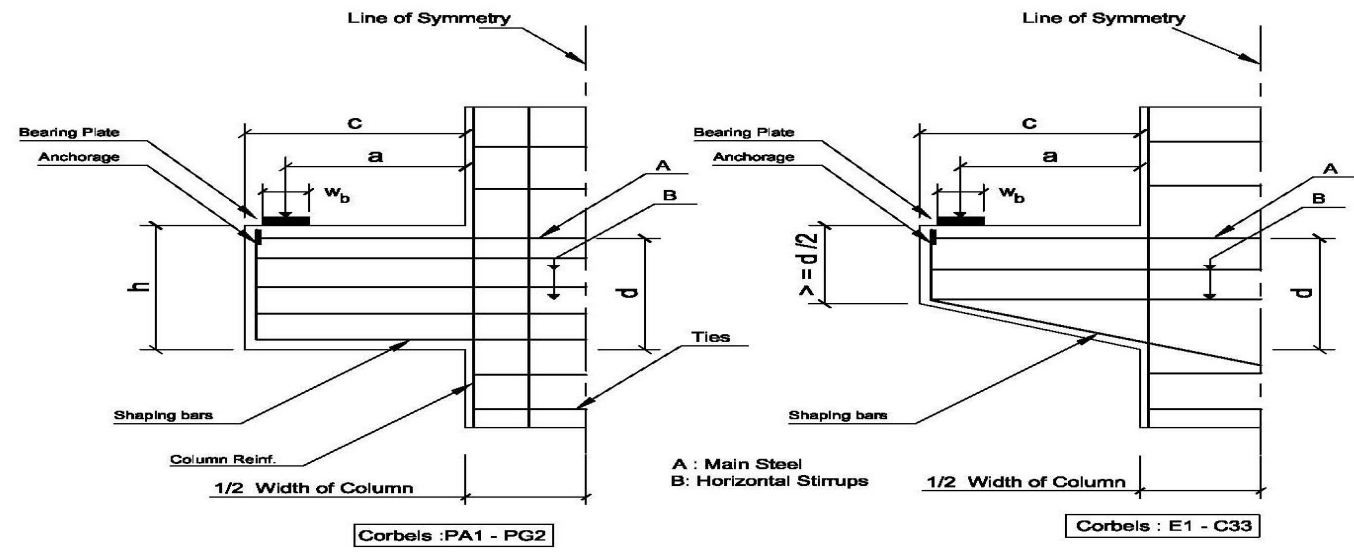

Fig.(2)- Details of test specimens

(a) Experimental

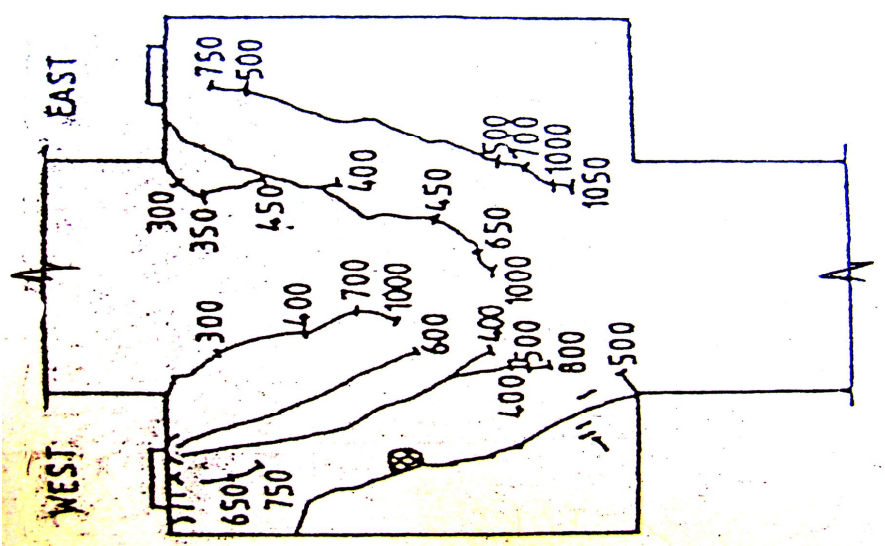

(b) Numerical

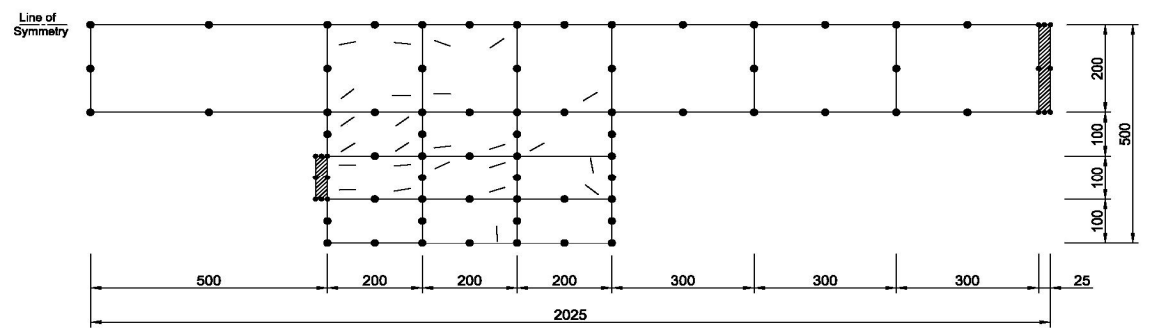

Fig.(3)- Crack pattern for corbel PF2 at failure 


\section{$\begin{array}{llll}\text { Al-Rafidain Engineering } & \text { Vol.17 } & \text { No.4 } & \text { August } 2009\end{array}$}

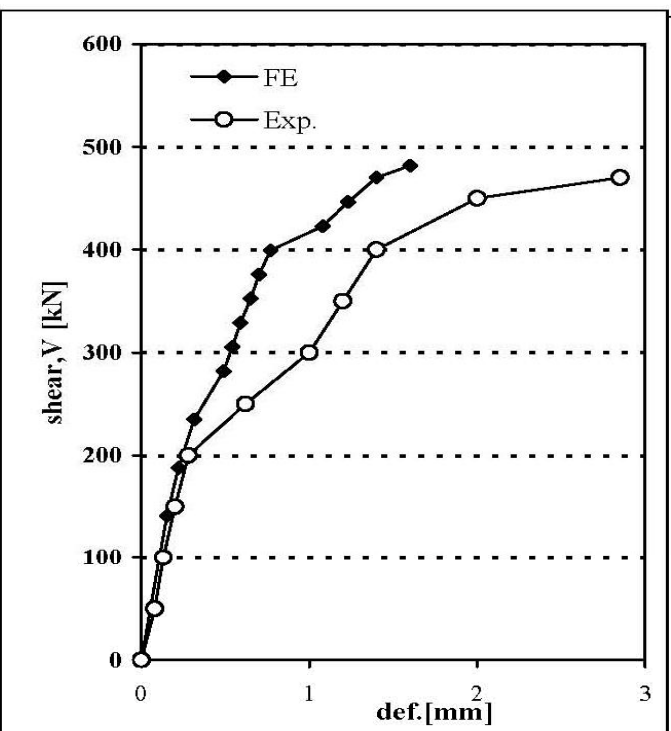

Fig.(4)- Load- deflection relationships for corbel $\mathrm{SC} 1-4[8]$

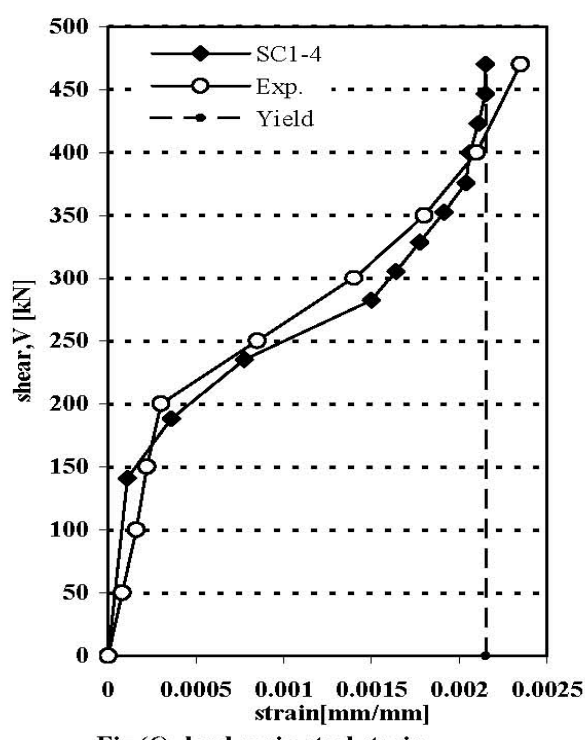

Fig.(6)- load-main steel strain relationships for corbel SC 1-4[8]

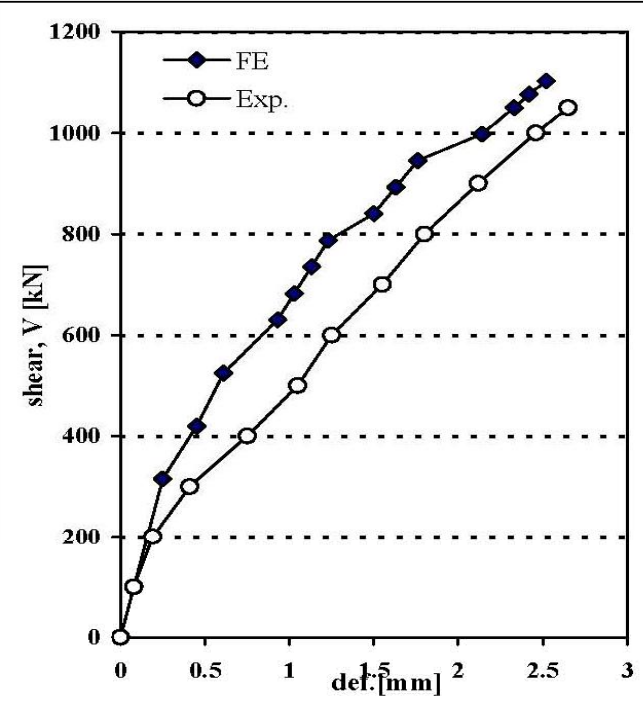

Fig.(5)- Load-deflection relationships for corbel PG2 [8]

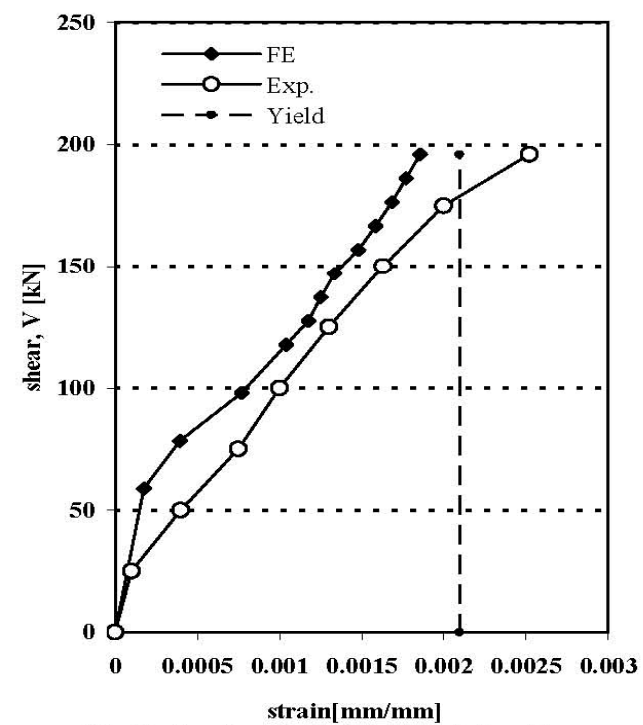

Fig.(7)- Load-main steel strain relationships for corbel C9[9]

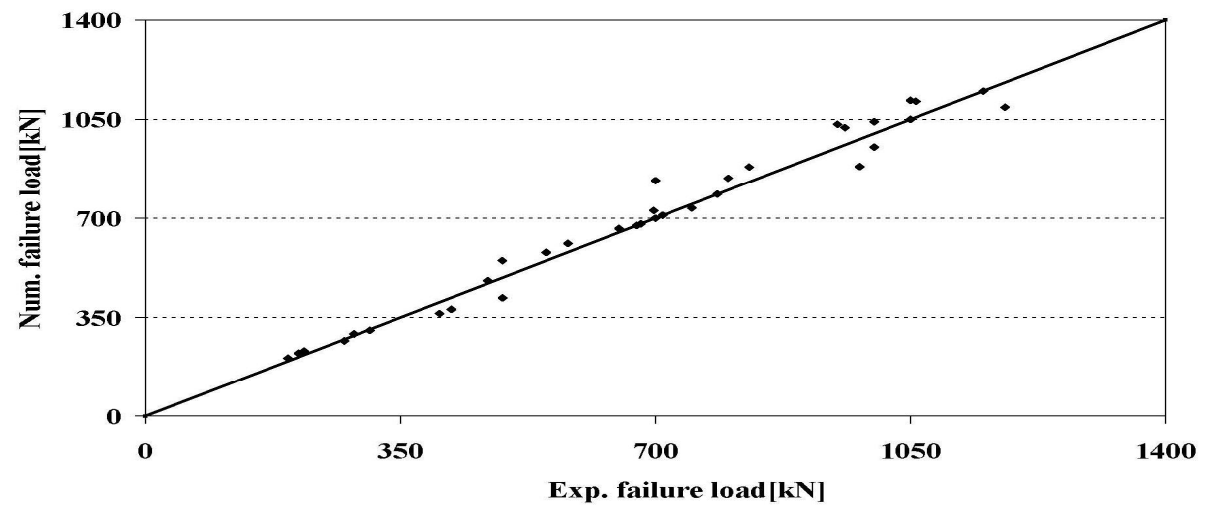

Fig.(8)- Correlation between experimental and numerical failure loads using the finite elem ent $m$ ethod 


\section{2-Strut-and-Tie Model (Truss Analogy)}

Strut-and-tie models are most appropriately used for the design of disturbed regions, or D regions. These D regions are characterized by a complex flow of internal stresses and include regions adjacent to discontinuities caused by abrupt changes of cross section or the presence of concentrated loads or reactions (corbels, deep beams, dapped-end beams, and anchorage zones at the end of prestressed beams). In the design of these disturbed regions, it is inappropriate to assume that plane sections remain plane or that the shear stress is uniform over the depth of the member, therefore the standard design rules for flexure and shear do not apply. The structural damage as reported by Reineck [23] and Fung and Ing [24], has shown that it is unsatisfactory to rely on empirical approaches and rule of thumb for the design of such important regions. It was found [25-31] that the use of reasonable strut-and-tie models is suitable for the design of such regions. ACI 318-02 and later codes [32] permitted the use of strut-and-tie models for the design of discontinuity regions.

In this study a simple strut-and-tie model was used for the prediction of the maximum load capacity of high-strength reinforced concrete corbels. The plastic truss model, shown in Fig. 9, consists of prismatic compression struts in uniaxial compression with a uniform distribution of stress across the struts and a tension tie. The strut width $\mathrm{w}_{\mathrm{s}}$ is defined by the geometry of the nodes [32] (see Fig. 9b):

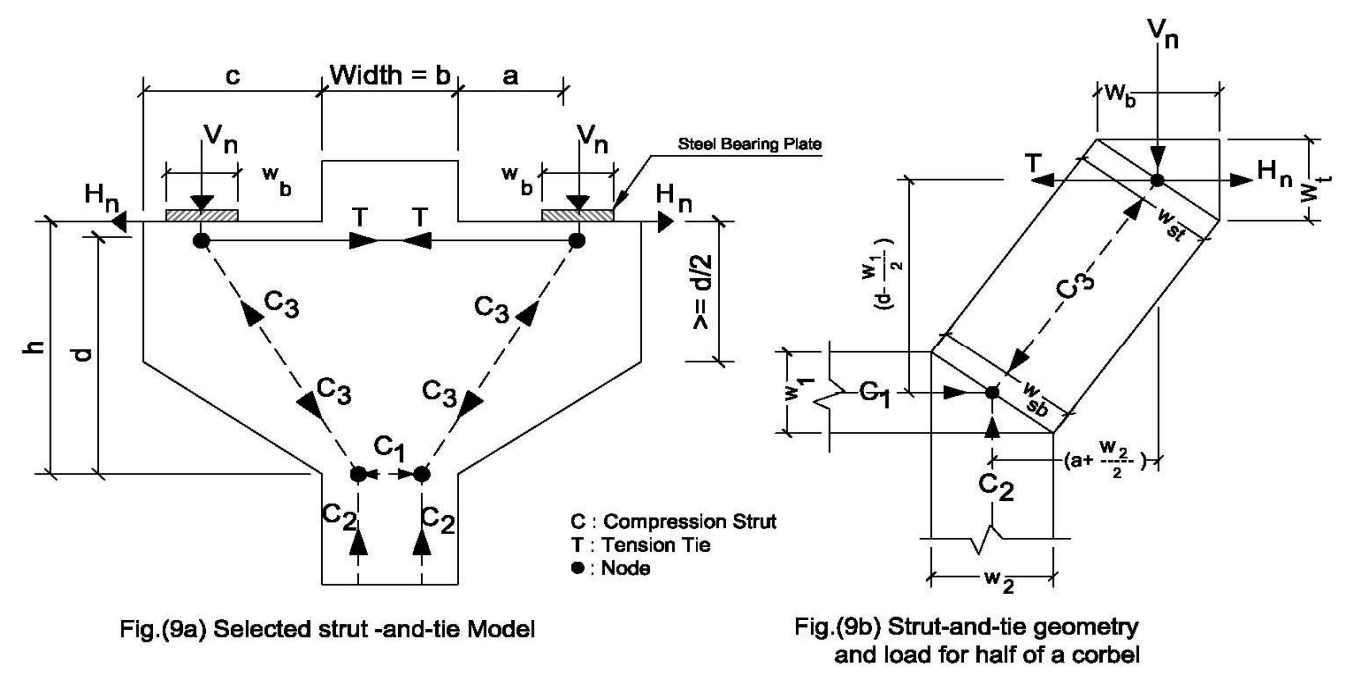

Fig.(9)- Simulation of a corbel by a strut -and-tie model

At top: $\mathrm{w}_{\mathrm{st}}=\mathrm{w}_{\mathrm{b}} \sin \theta+\mathrm{w}_{\mathrm{t}} \cos \theta$
At bottom: $\mathrm{w}_{\mathrm{sb}}=\mathrm{w}_{2} \sin \theta+\mathrm{w}_{1} \cos \theta$

Where:

$\mathrm{W}_{\mathrm{st}}=$ width of the inclined strut at the top node, $\mathrm{mm}$,

$\mathrm{w}_{\mathrm{sb}}=$ width of the inclined strut at the bottom node, $\mathrm{mm}$,

$\mathrm{w}_{\mathrm{b}}=$ width of the bearing plate at the support, $\mathrm{mm}$,

$\mathrm{w}_{\mathrm{t}}=$ width of the horizontal tie, $\mathrm{mm}$,

$\mathrm{w}_{2}=$ width of the vertical strut at the bottom node, $\mathrm{mm}$,

$\mathrm{w}_{1}=$ width of the horizontal strut at the bottom node, $\mathrm{mm}$, and

$\theta=$ inclination of the inclined strut $\left(\mathrm{C}_{3}\right)$, degree.

This model is chosen due its simplicity. In this model, only two failure modes are possible: failure by crushing of the concrete in the compression struts (usually the inclined strut) and failure by yielding of the tension tie. Other types of failure such as bearing and 


\section{$\begin{array}{llll}\text { Al-Rafidain Engineering } & \text { Vol.17 } & \text { No.4 } & \text { August } 2009\end{array}$}

anchorage failures can be avoided by good detailing. The allowable concrete compressive stresses are those specified in the appendix A of the ACI 318-05 Code [32].

The analysis is simply started by assuming plasticity in the tension tie (i.e. the main tensile reinforcement reaches its yield strength, $\mathrm{f}_{\mathrm{y}}$ ), and accordingly the value of $\mathrm{w}_{1}, \mathrm{w}_{2}, \mathrm{w}_{\mathrm{t}}$, and $\mathrm{w}_{\mathrm{st}}$ is determined. Two typical examples for the analysis of the failure load capacity of high-strength concrete corbels are given in Appendix A of this paper.

The plastic truss model used does not consider the effect of the secondary reinforcement (shear reinforcement) in increasing the capacity of the specimens, although a more complex model could. The difficulty in adopting a more advanced model is in guaranteeing that all the secondary reinforcement is at yield at failure. In the author's opinion, it is the role of the secondary reinforcement to guard against interface shear and diagonal splitting failures and to improve the performance of the compression strut by reducing transverse strains which may adversely affected the strut capacity as reported by Vecchio and Collins [15]. On the other hand, when the secondary reinforcement reaches yielding, serious cracks (deep extension of crack and large crack width) were formed which made the structural member to be beyond its serviceability limits.

The results of the analysis, as shown in Table 2 and Fig. 10, showed that the strut-andtie model adopted here is an effective tool for design of high-strength concrete corbels with the efficiency factors of the ACI 318-05 Code [32]. An additional advantage of using strutand-tie models is that sketching the flow of the forces within a member highlights the need for careful details of the reinforcement in key regions.

The non-linear finite element analysis showed that the average tensile stress in the main reinforcement of corbel PB2 (for example), $f_{s}$, was less than the yield stress $\left(f_{y}=495\right.$ $\mathrm{MPa})$. If this value of the steel stress $\left(\mathrm{f}_{\mathrm{s}}=195 \mathrm{MPa}\right)$ is used in the truss model instead of $\mathrm{f}_{\mathrm{y}}$, the value of $\mathrm{V}_{\text {test }} / \mathrm{V}_{\text {calc. }}=1.14$, which is conservative when compared with 0.76 (based on $\mathrm{f}_{\mathrm{s}}=\mathrm{f}_{\mathrm{y}}$ ). Therefore, the finite element method can be considered as a powerful tool for checking the design of corbels, and in predicting the structural behavior of such members easily. Also nonlinear finite element analysis can be used as a reliable alternative for the costly procedure for the prediction of the structure behavior.

\section{Parametric Study}

An overview of the predicted results shows good agreement with those obtained from experiments. This proves the reliability of both method for analysis and design. A study was carried out into the influence of parameters variation. This study analyses the influence of: (1) the shear-span-to-depth ratio $(\mathrm{a} / \mathrm{d}),(2)$ the compressive strength of concrete $\left(\mathrm{f}^{\prime}{ }_{\mathrm{c}}\right)$, and (3) percentage of main steel $(\rho)$.

In general, the results of the parametric study showed that the adopted finite element model is not affected by the range of variables studied, while the truss model was less or not conservative for high values of a/d and high content of main tensile steel especially in the absence of shear reinforcement, see Figs. (11-13). 


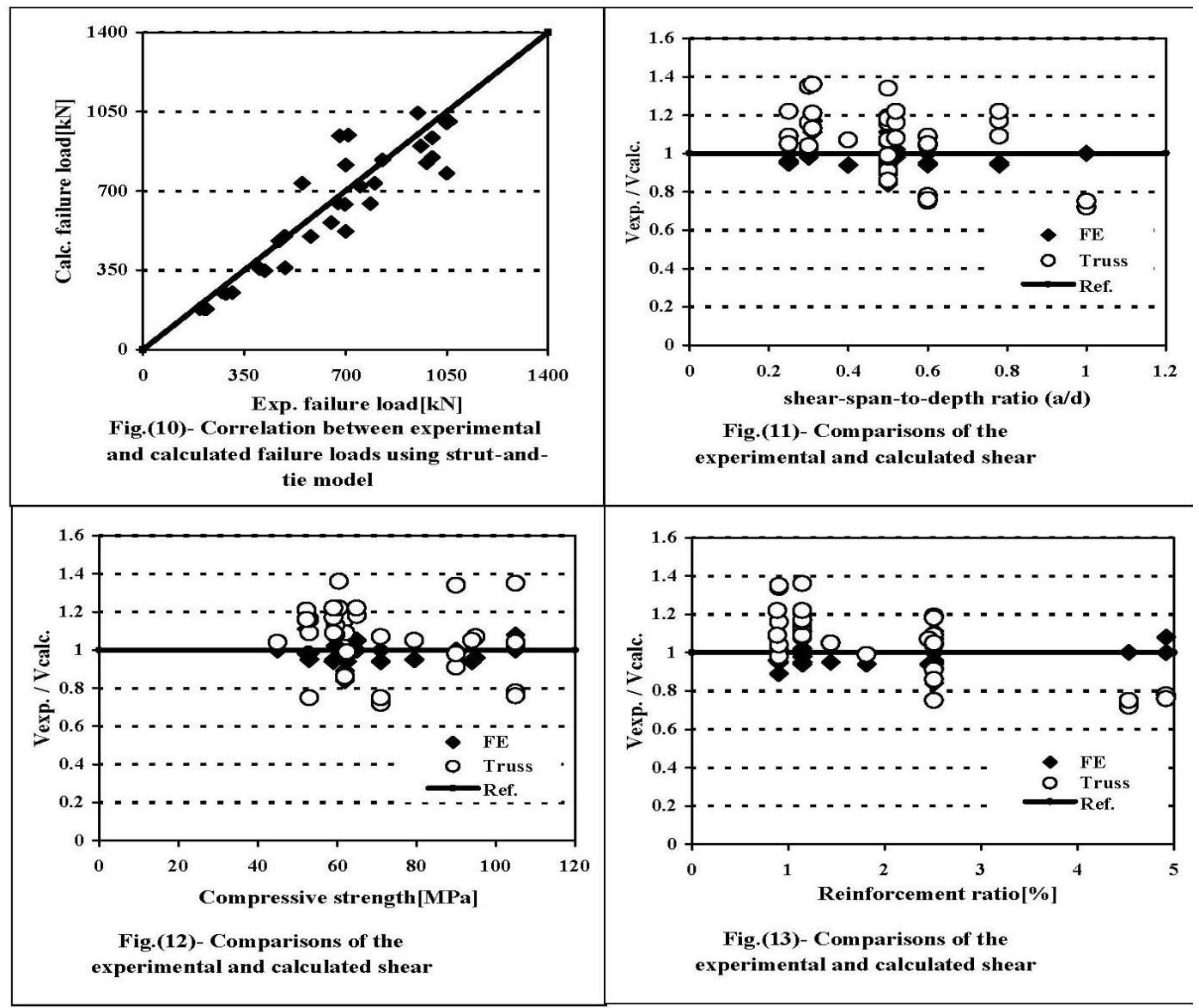

\section{Conclusions}

Based on the available test results in the literature and their comparisons with the numerical method (finite element) and analytical method (strut-and-tie model), the following conclusions can be made:

1-The reinforced-concrete plasticity model combined with concrete cracking model, tension stiffening, compression softening, and cracked concrete shear modulus proved to be a suitable model when used in the finite element method for the analysis of high-strength reinforced concrete corbels.

2-The parametric study showed that the finite element model used is equally applicable for the range of the variables studied, i.e. the results are not affected whether the variables have low or high values. Therefore, it can be concluded that the method is a powerful tool for the analysis of such disturbed region, and to assure the safety requirements for dangerous locations. The numerical analysis is also helpful in constructing reasonable strut-and-tie models for these structures.

3-Strut-and-tie modeling provides the designer with a simple, yet powerful tool for the design of nonflexural reinforced concrete members. The flow of forces in such members is idealized as a truss consisting of concrete struts and steel reinforcement ties connected at nodes.

4-The results indicated that the proposed simple truss model is effective and gives reasonable predictions of the failure load capacity of high-strength reinforced concrete corbels. 


\section{$\begin{array}{llll}\text { Al-Rafidain Engineering } & \text { Vol.17 } & \text { No.4 } & \text { August } 2009\end{array}$}

5-Unlike the finite element model adopted, the strut-and-tie model was affected by the values of the variables. Also it was affected by absence or the presence of the web reinforcement. Conservative results were obtained when the corbel specimen contains web reinforcement and has low percentage of main reinforcement especially for low shear span-to-depth ratio. In general, the results are more or less conservative when the corbel contains high percentage of main steel and without shear reinforcement; such corbels fail before the main steel reaches yielding. Therefore, a minimum amount of shear reinforcement, specified by the codes of practice, should be provided when the design is performed by the truss analogy (strut-and-tie model).

Table 1- Details and dimensions of test specimens

\begin{tabular}{|c|c|c|c|c|c|c|c|c|c|c|}
\hline \multirow{2}{*}{$\begin{array}{c}\text { Corb. } \\
\text { No. }\end{array}$} & \multirow{2}{*}{$\begin{array}{l}f^{\prime} \mathrm{c}, \\
\mathrm{MPa}\end{array}$} & \multicolumn{5}{|c|}{ Dimensions, mm } & \multicolumn{2}{|c|}{$\begin{array}{c}\text { Main } \\
\text { reinforcement }\end{array}$} & \multicolumn{2}{|c|}{$\begin{array}{c}\text { Secondary } \\
\text { reinforcement }\end{array}$} \\
\hline & & a & c & $d^{*}$ & $\mathbf{w}_{\mathrm{b}}$ & $\begin{array}{c}\text { Thick } \\
\mathbf{t}\end{array}$ & A & $\begin{array}{c}f_{y}, \\
M P a\end{array}$ & B & $\begin{array}{r}\mathbf{f}_{\mathrm{y}} \\
\mathrm{MPa}\end{array}$ \\
\hline \multicolumn{11}{|l|}{$\begin{array}{l}\text { Ref. } \\
\text { No. } 8\end{array}$} \\
\hline SC1-2 & 90.0 & 300 & 425 & 600 & 125 & 125 & $6 \Phi 20$ & 430 & Nil & ---- \\
\hline SC1-3 & 90.0 & 300 & 425 & 600 & 125 & 125 & $6 \Phi 12$ & 430 & $12 \Phi 6$ & 420 \\
\hline SC1-4 & 90.0 & 330 & 425 & 600 & 125 & 125 & $6 \Phi 12$ & 430 & Nil & ---- \\
\hline SC2-1 & 62.0 & 300 & 425 & 600 & 125 & 125 & $6 \Phi 20$ & 430 & $12 \Phi 6$ & 420 \\
\hline SC2-2 & 62.0 & 300 & 425 & 600 & 125 & 125 & $6 \Phi 20$ & 430 & Nil & +--- \\
\hline SC2-3 & 62.0 & 300 & 425 & 600 & 125 & 125 & $6 \Phi 12$ & 430 & $12 \Phi 6$ & 420 \\
\hline SC2-4 & 62.0 & 300 & 425 & 600 & 125 & 125 & $6 \Phi 12$ & 430 & Nil & ---- \\
\hline SD1 & 95.0 & 300 & 425 & 600 & 100 & 125 & $6 \Phi 20$ & 430 & $12 \Phi 6$ & 420 \\
\hline $\begin{array}{l}\text { SD2 } \\
\end{array}$ & 65.0 & 300 & 425 & 600 & 125 & 125 & $6 \Phi 20$ & 430 & $12 \Phi 6$ & 420 \\
\hline PA1 & 53.0 & 300 & 400 & 500 & 100 & 150 & $6 \Phi 20$ & 450 & Nil & ---- \\
\hline PA2 & 53.0 & 300 & 400 & 500 & 100 & 150 & $6 \Phi 20$ & 450 & $10 \Phi 10$ & 360 \\
\hline PB1 & 105.0 & 300 & 400 & 500 & 100 & 150 & $6 \Phi 28$ & 495 & Nil & ---- \\
\hline PB2 & 105.0 & 300 & 400 & 500 & 100 & 150 & $6 \Phi 28$ & 495 & $10 \Phi 10$ & 360 \\
\hline PC1 & 53.0 & 150 & 300 & 500 & 100 & 150 & $6 \Phi 12$ & 420 & Nil & ---- \\
\hline PC2 & 53.0 & 150 & 300 & 500 & 100 & 150 & $6 \Phi 12$ & 420 & $10 \Phi 10$ & 360 \\
\hline PD2 & 71.0 & 200 & 300 & 500 & 100 & 150 & $3 \Phi 28$ & 450 & $10 \Phi 10$ & 360 \\
\hline PE1 & 71.0 & 450 & 550 & 450 & 100 & 150 & $3 \Phi 36$ & 480 & Nil & +--- \\
\hline PE2 & 71.0 & 450 & 550 & 450 & 100 & 150 & $3 \Phi 36$ & 480 & $10 \Phi 10$ & 360 \\
\hline PF1 & 105.0 & 150 & 300 & 500 & 100 & 150 & $6 \Phi 12$ & 420 & NiI & --- \\
\hline PF2 & 105.0 & 150 & 300 & 500 & 100 & 150 & $6 \Phi 12$ & 420 & $10 \Phi 10$ & 360 \\
\hline PG1 & 45.0 & 300 & 450 & 500 & 100 & 150 & $6 \Phi 20$ & 415 & $8 \Phi 6$ & 490 \\
\hline PG2 & 94.0 & 300 & 450 & 500 & 100 & 150 & $6 \Phi 20$ & 415 & $8 \Phi 6$ & 490 \\
\hline \multicolumn{11}{|l|}{$\begin{array}{c}\text { Ref. } \\
\text { No. } 7 \\
\end{array}$} \\
\hline E1 & 62.1 & 89 & 254 & 356 & 90 & 254 & $4 \Phi 16$ & 420 & $4 \Phi 10$ & 420 \\
\hline E2 & 64.9 & 89 & 254 & 356 & 90 & 254 & $4 \Phi 16$ & 420 & $4 \Phi 10$ & 420 \\
\hline E3 & 79.5 & 89 & 254 & 356 & 90 & 254 & $\begin{array}{r}2 \Phi 25 \\
+1 \Phi 18\end{array}$ & 420 & $8 \Phi 10$ & 420 \\
\hline F1 & 82.2 & 178 & 254 & 356 & 90 & 254 & $5 \Phi 16$ & 420 & $6 \Phi 10$ & 420 \\
\hline F2 & 62.5 & 178 & 254 & 356 & 90 & 254 & $2 \Phi 30$ & 420 & $8 \Phi 10$ & 420 \\
\hline \multicolumn{11}{|l|}{$\begin{array}{l}\text { Ref. } \\
\text { No. } 9\end{array}$} \\
\hline C1 & 59.6 & 69 & 250 & 220 & 100 & 150 & $3 \Phi 12$ & 419 & Nil & 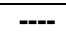 \\
\hline C5 & 59.6 & 115 & 250 & 220 & 100 & 150 & $3 \Phi 12$ & 419 & Nil & -.-- \\
\hline C9 & 59.2 & 173 & 250 & 220 & 100 & 150 & $3 \Phi 12$ & 419 & Nil & ---- \\
\hline C13 & 52.3 & 69 & 250 & 220 & 100 & 150 & $3 \Phi 12$ & 419 & $4 \Phi 4$ & 431 \\
\hline C17 & 52.3 & 115 & 250 & 220 & 100 & 150 & $3 \Phi 12$ & 419 & $4 \Phi 4$ & 431 \\
\hline C21 & 59.1 & 173 & 250 & 220 & 100 & 150 & $3 \Phi 12$ & 419 & $4 \Phi 4$ & 431 \\
\hline C25 & 60.5 & 69 & 250 & 220 & 100 & 150 & $3 \Phi 12$ & 419 & $2 \Phi 8$ & 289 \\
\hline C29 & 60.5 & 115 & 250 & 220 & 100 & 150 & $3 \Phi 12$ & 419 & $2 \Phi 8$ & 289 \\
\hline C33 & 59.1 & 173 & 250 & 220 & 100 & 150 & $3 \Phi 12$ & 419 & $2 \Phi 8$ & 289 \\
\hline
\end{tabular}

$(\mathrm{h}-\mathrm{d})=\mathbf{1 0 0} \mathrm{mm}$ for corbels of Ref. 8; $=50 \mathrm{~mm}$ for corbels of Ref. $7 ; \quad=40$ mm for corbels of Ref. 9. 
Table 2- Comparison of Experimental and Analytical Results

\begin{tabular}{|c|c|c|c|c|c|c|}
\hline \multirow{2}{*}{$\begin{array}{c}\text { Corbel } \\
\text { No. }\end{array}$} & \multirow{2}{*}{$a / d$} & \multirow{2}{*}{$\begin{array}{l}f^{\prime} \mathrm{c}, \\
\mathrm{MPa}\end{array}$} & \multirow{2}{*}{$\frac{100 A_{s}^{*}}{b d}$} & \multirow{2}{*}{$\begin{array}{c}\mathbf{V}_{\text {test }} \\
\text { KN }\end{array}$} & \multicolumn{2}{|c|}{$\mathrm{V}_{\text {test }} / \mathrm{V}_{\text {calc. }}$} \\
\hline & & & & & FEM & Truss analogy \\
\hline SC1-2 & 0.50 & 90.0 & 2.512 & 950.0 & 0.92 & 0.91 \\
\hline SC1-3 & 0.50 & 90.0 & 0.904 & 700.0 & 1.00 & 1.34 \\
\hline SC1-4 & 0.50 & 90.0 & 0.904 & 470.0 & 0.98 & 0.98 \\
\hline SC2-1 & 0.50 & 62.0 & 2.512 & 980.0 & 1.11 & 1.19 \\
\hline SC2-2 & 0.50 & 62.0 & 2.512 & 700.0 & 0.84 & 0.86 \\
\hline SC2-3 & 0.50 & 62.0 & 0.904 & 580.0 & 0.95 & 1.16 \\
\hline SC2-4 & 0.50 & 62.0 & 0.904 & 490.0 & 0.89 & 0.98 \\
\hline SD1 & 0.50 & 95.0 & 2.512 & 1000.0 & 0.96 & 1.07 \\
\hline SD2 & 0.50 & 65.0 & 2.512 & 1000.0 & 1.05 & 1.18 \\
\hline PA1 & 0.60 & 53.0 & 2.512 & 550.0 & 0.95 & 0.75 \\
\hline PA2 & 0.60 & 53.0 & 2.512 & 800.0 & 0.95 & 1.09 \\
\hline PB1 & 0.60 & 105.0 & 4.920 & 1180.0 & 1.08 & 0.78 \\
\hline PB2 & 0.60 & 105.0 & 4.920 & 1150.0 & 1.00 & 0.76 \\
\hline PC1 & 0.30 & 53.0 & 0.904 & 650.0 & 0.98 & 1.16 \\
\hline PD2 & 0.40 & 71.0 & 2.460 & 960.0 & 0.94 & 1.07 \\
\hline PE1 & 1.00 & 71.0 & 4.534 & 680.0 & 1.00 & 0.72 \\
\hline PE2 & 1.00 & 71.0 & 4.534 & 710.0 & 1.00 & 0.75 \\
\hline PF1 & 0.30 & 105.0 & 0.904 & 750.0 & 1.02 & 1.04 \\
\hline PF2 & 0.30 & 105.0 & 0.904 & 1050.0 & 1.00 & 1.35 \\
\hline PG1 & 0.60 & 45.0 & 2.512 & 674.0 & 1.00 & 1.04 \\
\hline PG2 & 0.60 & 94.0 & 2.512 & 1050.0 & 0.94 & 1.05 \\
\hline E1 & 0.25 & 62.1 & 0.885 & 697.8 & 0.96 & 1.09 \\
\hline E2 & 0.25 & 64.9 & 0.885 & 785.1 & 1.00 & 1.22 \\
\hline E3 & 0.25 & 79.5 & 1.441 & 1057.7 & 0.95 & 1.05 \\
\hline F2 & 0.50 & 62.5 & 1.813 & 828.7 & 0.94 & 0.99 \\
\hline C1 & 0.31 & 59.6 & 1.145 & 403.9 & 1.11 & 1.13 \\
\hline C5 & 0.52 & 59.6 & 1.145 & 273.1 & 1.02 & 1.08 \\
\hline C9 & 0.78 & 59.2 & 1.145 & 196.0 & 0.95 & 1.09 \\
\hline C13 & 0.31 & 52.3 & 1.145 & 420.0 & 1.11 & 1.21 \\
\hline C17 & 0.52 & 52.3 & 1.145 & 286.4 & 0.98 & 1.16 \\
\hline C21 & 0.78 & 59.1 & 1.145 & 210.7 & 0.94 & 1.17 \\
\hline C25 & 0.31 & 60.5 & 1.145 & 490.1 & 1.17 & 1.36 \\
\hline C29 & 0.52 & 60.5 & 1.145 & 308.1 & 1.01 & 1.22 \\
\hline C33 & 0.78 & 59.1 & 1.145 & 218.0 & 0.94 & 1.22 \\
\hline \multicolumn{5}{|c|}{ Mean } & 0.99 & 1.065 \\
\hline \multicolumn{5}{|c|}{ Standard Deviation } & 0.066 & 0.170 \\
\hline \multicolumn{5}{|c|}{ Coefficient of Variation (C.O.V.) } & 6.7 & 16.0 \\
\hline
\end{tabular}

${ }^{*} A_{s}$ represents the area of main tensile steel

\section{References}

1- Kriz, L. B., and Raths, C. H., " Connections in Precast Concrete Structures-Strength of Corbels ", PCI Journal, Vol.10, No.1, February, 1965, pp. 16-61.

2- Clark, J. L., " Behavior and Design of Small Continuous Corbels ", Technical Report No.42-513, Cement and Concrete Association, Wexham Springs, March, 1976, 11 pp.

3- Mattock, A. H., Cheng, K. C., and Soongswang, K., " The Behavior of Reinforced Concrete Corbels ", PCI Journal, March-April, 1976, pp. 53-77.

4- Futtuhi, N. I., " Corbels with Shear Reinforcement in the Form of Stirrups or Fibers ", Proceeding, RILEM Symposium on Developments in Fiber Reinforced Cement and Concrete, University of Sheffield, July, 1986, Vol.2, Paper No.8.8.

5- Chakarbarti, P. R., Farahani, D. J., and Kashou, S. I., " Reinforced and Precompressed Concrete Corbels-An Experimental Study ", ACI Structural Journal, Vol.86, No.4, July-August, 1989, pp. 405-412.

6- Futtuhi, N. I., and Hughes, B. P., " Ductility of Reinforced Concrete Corbels Containing either Steel Fibers or Stirrups ", ACI Structural Journal, Vol.86, No.6, November-December, 1989, pp. 644-651. 


\section{$\begin{array}{llll}\text { Al-Rafidain Engineering } & \text { Vol.17 } & \text { No.4 } & \text { August } 2009\end{array}$}

7- Yong, Y-K., and Balaguru, P., " Behavior of Reinforced High-Strength Concrete Corbels ", Journal of Structural Engineering, ASCE, Vol.120, No.4, April, 1994, pp. 1182-1201.

8- Foster, S. J., Powell, R. E., and Selim, H. S., " Performance of High-Strength Concrete Corbels ", ACI Structural Journal, Vol.93, No.5, September-October, 1996, pp. 555563.

9- Muhammad, A. H., " Behavior and Strength of High-Strength Fiber Reinforced Concrete Corbels Subjected to Monotonic or Cyclic Loading ", Ph.D. Thesis, University of Technology, Iraq, December, 1998.

10- Othman, Z. S., " Shear Strength and Behavior of Reinforced High-Strength Concrete Corbels ", M.Sc. Thesis, University of Salahaddin-Erbil, Iraq, September, 2005.

11- Chen, W. F., " Plasticity in Reinforced Concrete ", McGraw-Hill Book Company, 1982.

12- Figueiras, J. A., " Practical Approach for Modeling the Nonlinear Response of RC Shells ", in Computational Modeling of Reinforced Concrete Structures, edited by E. Hinton and R. Owen, Pineridge Press Limited, Swansea, 1986, pp. 217-253.

13- Kupfer, H., Hilsdorf, H. K., and Rush, H., " Behavior of Concrete under Biaxial Stresses ", ACI Journal, Vol.66, No.8, August, 1969, pp. 656-666.

14- Cervera, M., and Hinton, E., " Nonlinear Analysis of Reinforced Concrete Plates and Shells Using a Three Dimensional Model ", in Computational Modeling of Reinforced Concrete Structures, edited by E. Hinton and R. Owen, Pineridge Press Limited, Swansea, 1986, pp. 327-370.

15- Vecchio, F. J., and Collins, M. P., " The Modified Compression Field Theory for Reinforced Concrete Elements Subjected to Shear ", ACI Journal, Vol.83, No.2, March-April, 1986, pp. 219-231.

16- Belarbi, A., and Hsu, T. T. C., " Constitutive Laws of Softened Concrete in Biaxial Tension-Compression ", ACI Structural Journal, Vol.92, No.5, September-October, 1995, pp. 562-573.

17- Kaufmann, W., and Marti, P., " Structural Concrete: Cracked Membrane Model ", Journal of the Structural Division, ASCE, Vol.124, No.12, December, 1998, pp. 14671475.

18- Abdul-Razzak, A. A., " Nonlinear Finite Element Analysis of Fibrous Reinforced Concrete Structural Members ", Ph.D. Thesis, Mosul University, Iraq, 1996.

19- Al-Mahaidi, R. S. H., " Nonlinear Finite Element Analysis of Reinforced Concrete Deep Members ", Ph.D. Thesis, Dept. of Structural Engineering, Cornell University, Ithaca, New York, May 1978.

20- Dong, Z., and Keru, W., " Fracture Properties of High-Strength Concrete ", Journal of Materials in Civil Engineering, ASCE, Vol.127, No.1, January-February, 2001, pp. $86-88$.

21- Hinton, E., and Owen, D. R. J., " Finite Element Programming ", Academic Press Inc., $3^{\text {rd }}$ Printing, 1980.

22- Mahmood, M. N., " Nonlinear Finite Element Analysis of Reinforced Concrete Deep Beams ", M.Sc. Thesis, Mosul University, Iraq, September, 1986.

23- Reineck, K. H., " Rational Methods for Detailing and Design; Strut-and-Tie Modeling ", Large Concrete Building, England, 1996.

24- Fung, I. K., and Ing, Y. L. M., " Strut-and-Tie Modes for the Design of Structural Concrete ", Workshop, Tainan, 1996.

25- Schlaich, J., Schafer, K., and Jennewein, M., " Toward a Consistent Design of Structural Concrete ", PCI Journal, Vol.32, No.3, May-June, 1987, pp. 74-150. 
26- Marti, P., " Basic Tools of Reinforced Concrete Beam Design ", ACI Journal, Vol.82, No.1, January-February, 1985, pp. 46-56.

27- Hwang, S-J., and Lee, H-J., " Strength Prediction for Discontinuity Regions by Softened Strut-and-Tie Model ", Journal of Structural Engineering, ASCE, Vol.128, No.12, December, 2002, pp. 818-828.

28- Foster, S. J., " Design of Non-Flexural Members for Shear ", Cement and Concrete Composites, Elsevier Science Ltd., 20, 1998, pp. 465-475.

29- Foster, S. J., and Gilbert, R. I., " The Design of Non-Flexural Members with Normal and High-Strength Concrete ", ACI Structural Journal, Vol.93, No.1, January-February, 1996, pp. 3-10.

30- Hwang, S-J., Lu, W-Y., and Lee, H-J., " Shear Strength Prediction for Reinforced Concrete Corbels ", ACI Structural Journal, Vol.97, No.4, July-August, 2000, pp. 543552.

31- ACI Subcommittee 445-1, " Examples for the Design of Structural Concrete with Strut-and-Tie Models ", ACI SP-208, Edited by Karl-Heinz Reineck, American Concrete Institute, Farmington Hills, M1, 2002.

32- ACI Committee 318, "Building Code Requirements for Structural Concrete and Commentary ACI 318-05 ", American Concrete Institute, 2005.

\section{Appendix A}

\section{Corbel PG2 - Vertical Load:}

$\mathrm{f}{ }_{\mathrm{c}}=94 \mathrm{MPa} ; \mathrm{a}=300 \mathrm{~mm} ; \mathrm{d}=500 \mathrm{~mm} ; \mathrm{a} / \mathrm{d}=0.6 ; \mathrm{w}_{\mathrm{b}}=100 \mathrm{~mm}$; corbel thickness $=150 \mathrm{~mm}$; $\mathrm{A}_{\mathrm{s}}=6 \Phi 20 ; \mathrm{f}_{\mathrm{y}}=415 \mathrm{MPa} ; \mathrm{A}_{\mathrm{h}}=8 \Phi 6 ; \mathrm{V}_{\text {test }}=1050 \mathrm{kN}$.

Based on Fig.9: $\quad \mathrm{T}=\mathrm{A}_{\mathrm{s}} \cdot \mathrm{f}_{\mathrm{y}}=6(314)(415) \times 10^{-3}=781.86 \quad \mathrm{kN} ; \quad \mathrm{C}_{1}=0.85 \beta_{\mathrm{n}} . \quad \mathrm{f}^{\prime} \cdot \mathrm{w}_{1} \cdot \mathrm{t} \quad$; $\mathrm{C}_{1}=0.85(1.0)(94)\left(\mathrm{w}_{1}\right)(150) \times 10^{-3}=11.985 \mathrm{w}_{1} \mathrm{kN}$. Note: $\beta_{\mathrm{n}}=1.0$ for C-C-C node. $\sum \mathrm{F}_{\mathrm{x}}=0$ $\rightarrow \mathrm{C}_{1}=\mathrm{T} \rightarrow \mathrm{w}_{1}=65.2 \mathrm{~mm} ; \mathrm{T}=0.85 \beta_{\mathrm{n}} . \mathrm{f}^{\prime}{ }_{\mathrm{c}} \cdot \mathrm{w}_{\mathrm{t}} . \mathrm{t} \rightarrow \mathrm{w}_{\mathrm{t}}=81.54 \mathrm{~mm}$; Note: $\beta_{\mathrm{n}}=0.80$ for C$\mathrm{C}-\mathrm{T}$ node.

$\mathrm{C}_{2}=0.85 \beta_{\mathrm{n}} \cdot \mathrm{f}^{\prime}{ }_{\mathrm{c}} \cdot \mathrm{w}_{2} \cdot \mathrm{t}=0.85(1.0)(94)\left(\mathrm{w}_{2}\right)(150) \times 10^{-3}=11.985 \mathrm{w}_{2} \mathrm{kN}$.

$\sum \mathrm{M}=0$ at the upper node $\rightarrow \mathrm{C}_{1}\left(\mathrm{~d}-\mathrm{w}_{1} / 2\right)=\mathrm{C}_{2}\left(\mathrm{a}+\mathrm{w}_{2} / 2\right) \rightarrow \mathrm{w}_{2}=88.6 \quad \mathrm{~mm} ; \quad \theta=\tan ^{-1}\{(\mathrm{~d}-$ $\left.\left.\mathrm{w}_{1} / 2\right) /\left(\mathrm{a}+\mathrm{w}_{2} / 2\right)\right\}=53.6$ degree. At top: $\mathrm{w}_{\mathrm{st}}=\ell_{\mathrm{b}} \sin \theta+\mathrm{w}_{\mathrm{t}} \cos \theta=100 \sin 53.6+81.54 \cos 53.6=$ $128.9 \mathrm{~mm} \rightarrow \mathrm{C}_{3 \mathrm{t}}=0.85(0.80)(94)(128.9)(150) \times 10^{-3}=1235.9 \mathrm{kN}$.

At bottom: $\mathrm{w}_{\mathrm{sb}}=\mathrm{w}_{2} \sin \theta+\mathrm{w}_{1} \cos \theta=88.6 \sin 53.6+65.2 \cos 53.6=110 \mathrm{~mm} \rightarrow$ $\mathrm{C}_{3 \mathrm{~b}}=0.85(1.0)(94)(110)(150) \times 10^{-3}=1318.4 \mathrm{kN}>1235.9 \rightarrow \mathrm{C}_{3}=1235.9 \mathrm{kN}$.

At the top node: $\sum \mathrm{F}_{\mathrm{x}}=0 \rightarrow \mathrm{C}_{3} \cos \theta=\mathrm{T} \rightarrow \mathrm{C}_{3}=1317.6 \mathrm{kN}>1235.9 \mathrm{kN} \rightarrow \mathrm{C}_{3}=1235.9 \mathrm{kN}$. At the top node: $\sum \mathrm{F}_{\mathrm{y}}=0 \rightarrow \mathrm{C}_{3} \sin \theta=\mathrm{V}_{\mathrm{n}} \rightarrow \mathrm{V}_{\mathrm{n}}=1235.9 \sin 53.6=994.8 \mathrm{kN}$; $V_{\text {test }} / V_{\text {calc. }}=1050 / 994.8=1.05$.

\section{Corbel E1 - Vertical and Horizontal Loads:}

$\mathrm{f}^{\prime}{ }_{\mathrm{c}}=62.1 \mathrm{MPa} ; \mathrm{a}=89 \mathrm{~mm} ; \mathrm{d}=356 \mathrm{~mm} ; \mathrm{a} / \mathrm{d}=0.25 ; \mathrm{w}_{\mathrm{b}}=90 \mathrm{~mm}$; corbel thickness=254 mm; As $=800 \mathrm{~mm}^{2} ; \mathrm{f}_{\mathrm{y}}=420 \mathrm{MPa} ; \mathrm{A}_{\mathrm{h}}=4 \Phi 10 ; \mathrm{P}_{\text {test }}=711.6 \mathrm{kN}$.

Based on Fig.9: $\quad \mathrm{T}=\mathrm{A}_{\mathrm{s}} \cdot \mathrm{f}_{\mathrm{y}}=800(420) \times 10^{-3}=336 \quad \mathrm{kN} ; \quad \mathrm{C}_{1}=0.85 \beta_{\mathrm{n}} \cdot \mathrm{f}_{\mathrm{c}} \mathrm{c} \cdot \mathrm{w}_{1} \cdot \mathrm{t} \quad$; $\mathrm{C}_{1}=0.85(1.0)(62.1)\left(\mathrm{w}_{1}\right)(254) \times 10^{-3}=13.407 \mathrm{w}_{1} \mathrm{kN}$. Note: $\beta_{\mathrm{n}}=1.0$ for C-C-C node. $\sum \mathrm{F}_{\mathrm{y}}=0 \rightarrow$

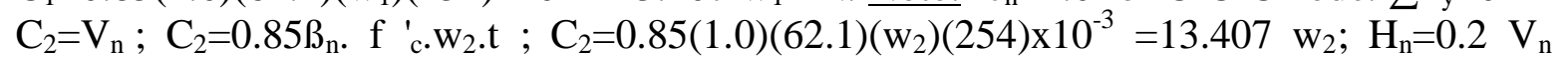
(specified in the test program); $\mathrm{H}_{\mathrm{n}}=2.681 \mathrm{w}_{2} \mathrm{kN} ; \quad \sum \mathrm{F}_{\mathrm{x}}=0 \rightarrow \mathrm{C}_{1}=\mathrm{T}-\mathrm{H}_{\mathrm{n}} \rightarrow 13.407 \mathrm{w}_{1}=336$ - $2.681 \mathrm{w}_{2}-------(1)$; 


\section{$\begin{array}{llll}\text { Al-Rafidain Engineering } & \text { Vol.17 } & \text { No.4 } & \text { August } 2009\end{array}$}

At the top node: $\quad \sum \mathrm{M}=0 \rightarrow \quad \mathrm{C}_{1}\left(\mathrm{~d}-\mathrm{w}_{1} / 2\right)=\mathrm{C}_{2}\left(\mathrm{a}+\mathrm{w}_{2} / 2\right) \rightarrow 13.407 \mathrm{w}_{1}(356-$ $\left.\mathrm{w}_{1} / 2\right)=13.407 \mathrm{w}_{2}\left(89+\mathrm{w}_{2} / 2\right)$---- (2); solving $(1) \&(2) \rightarrow \mathrm{w}_{1}=15.5 \mathrm{~mm} ; \mathrm{w}_{2}=47.8 \mathrm{~mm} ; \theta=\tan$ ${ }^{1}\left\{\left(\mathrm{~d}-\mathrm{w}_{1} / 2\right) /\left(\mathrm{a}+\mathrm{w}_{2} / 2\right)\right\}=72$ degree; $\mathrm{C}_{1}=640.9 \mathrm{kN} ; \mathrm{C}_{2}=207.8 \mathrm{kN} ; \mathrm{H}_{\mathrm{n}}=128.2 \mathrm{kN} ; \mathrm{w}_{\mathrm{t}}=\left(\mathrm{T}-\mathrm{H}_{\mathrm{n}}\right) /$ $\left(0.85 \beta_{\mathrm{n}} . \mathrm{f}^{\prime}{ }_{\mathrm{c}} \cdot \mathrm{t}\right)=19.4 \mathrm{~mm}$.

At top: $\mathrm{w}_{\mathrm{st}}=90 \sin 72+19.4 \cos 72=91.6 \mathrm{~mm}$; at bottom: $\mathrm{w}_{\mathrm{sb}}=47.8 \sin 72+15.5 \cos 72=50.3 \mathrm{~mm}<$ $0.8(91.6) \rightarrow \mathrm{w}_{\mathrm{s}}=\mathrm{w}_{\mathrm{sb}}=50.3 \mathrm{~mm} \rightarrow \mathrm{C}_{3 \mathrm{~b}}=0.85(1.0)(62.1)(50.3)(254) \times 10^{-3}=674.4 \mathrm{kN}$.

At the top node: $\sum \mathrm{F}_{\mathrm{x}}=0 \rightarrow \mathrm{C}_{3} \cos 72=\mathrm{T}-\mathrm{H}_{\mathrm{n}} \rightarrow \mathrm{C}_{3}=672.5 \mathrm{kN}<674.4 \mathrm{kN} \rightarrow \mathrm{C}_{3}=672.5$ $\mathrm{kN}$.

At the top node: $\sum \mathrm{F}_{\mathrm{y}}=0 \rightarrow \mathrm{C}_{3} \sin 72=\mathrm{V}_{\mathrm{n}} \rightarrow \mathrm{V}_{\mathrm{n}}=639.6 \mathrm{kN}$;

The test setup was designed to give $\mathrm{H}_{\mathrm{n}}=0.2 \mathrm{~V}_{\mathrm{n}}$ by using an inclined plate at an angle of 11.3 deg. with the horizontal. Therefore: $\mathrm{V}_{\text {test }}=\mathrm{P}_{\text {test }} \cos 11.3=711.6 \cos 11.3=697.8 \mathrm{kN}$; $\mathrm{V}_{\text {test }} / \mathrm{V}_{\text {calc. }}=6 \mathbf{6 9 7 . 8 / 6 3 9 . 6}=\mathbf{1 . 0 9}$. 